\title{
The effects of intermittent exposure to low-pH and low-oxygen conditions on survival and growth of juvenile red abalone
}

\author{
T. W. Kim ${ }^{1,2,3}$, J. P. Barry ${ }^{2}$, and F. Micheli ${ }^{3}$ \\ ${ }^{1}$ Korea Institute of Ocean Science and Technology, 787 Haeanro, Sangnok-gu, Ansan 426-744, South Korea \\ ${ }^{2}$ Monterey Bay Aquarium Research Institute, 7700 Sandholdt Road, Moss Landing, CA 95039, USA \\ ${ }^{3}$ Hopkins Marine Station, Stanford University, 120 Oceanview Blvd., Pacific Grove, CA 93950, USA
}

Correspondence to: T. W. Kim (ktwon@kiost.ac)

Received: 19 January 2013 - Published in Biogeosciences Discuss.: 26 February 2013

Revised: 10 September 2013 - Accepted: Accepted on 25 - Published: 13 November 2013

\begin{abstract}
Exposure of nearshore animals to hypoxic, low$\mathrm{pH}$ waters upwelled from below the continental shelf and advected near the coast may be stressful to marine organisms and lead to impaired physiological performance. We mimicked upwelling conditions in the laboratory and tested the effect of fluctuating exposure to water with low-pH and/or low-oxygen levels on the mortality and growth of juvenile red abalone (Haliotis rufescens, shell length 5-10 mm). Mortality rates of juvenile abalone exposed to low-pH (7.5, total scale) and low- $\mathrm{O}_{2}\left(40 \%\right.$ saturation, $\left.\mathrm{mg} \mathrm{L}^{-1}\right)$ conditions for periods of 3 to $6 \mathrm{~h}$ every 3-5 days over 2 weeks did not differ from those exposed to control conditions $\left(\mathrm{O}_{2}\right.$ : $100 \%$ saturation, $12 \mathrm{mg} \mathrm{L}^{-1}$; pH 8.0). However, when exposure was extended to $24 \mathrm{~h}$, twice over a 15 -day period, juveniles experienced 5-20\% higher mortality in the low-oxygen treatments compared to control conditions. Growth rates were reduced significantly when juveniles were exposed to lowoxygen and low-pH treatments. Furthermore, individual variation of growth rate increased when juveniles were exposed simultaneously to low- $\mathrm{pH}$ and low- $\mathrm{O}_{2}$ conditions. These results indicate that prolonged exposure to low-oxygen levels is detrimental for the survival of red abalone, whereas $\mathrm{pH}$ is a crucial factor for their growth. However, the high individual variation in growth rate under low levels of both $\mathrm{pH}$ and oxygen suggests that cryptic phenotypic plasticity may promote resistance to prolonged upwelling conditions by a portion of the population.
\end{abstract}

\section{Introduction}

Marine ecosystems are under threat from ocean acidification as the excess burden of fossil fuel $\mathrm{CO}_{2}$ dissolves into the ocean (Orr et al., 2005; Hofmann et al., 2010). Many studies of the biological effects of ocean acidification have focused on the predicted change of mean $\mathrm{pH}$ of ocean surface waters derived from IPCC climate scenarios (e.g., Bibby et al., 2007; Orr et al., 2005; Dupont et al., 2010; Byrne et al., 2011). However, nearshore environments are also influenced by low-pH, low-oxygen waters upwelled from below the continental shelf and advected to shallow nearshore environments (Grantham et al., 2004; Feely et al., 2008; Hauri et al., 2009). Even though the low-pH, low-oxygen conditions generally persist in the nearshore environment for only a few hours, this can happen routinely (50-200 times $\mathrm{yr}^{-1}$ ) in upwelling-driven ecosystems such as the California Current and Humboldt Current large marine ecosystems (GarciaReyes and Largier, 2010; Booth, 2011; Micheli et al., 2012).

It is assumed that many benthic animals living in nearshore marine environments either adapt to the local natural fluctuations of $\mathrm{pH}$ and dissolved oxygen (DO), or tolerate occasional short-lived exposure to potentially stressful conditions (Alenius and Munguia, 2012; Vaquer-Sunyer and Duarte, 2008). Nevertheless, more frequent and prolonged upwelling or hypoxic events induced by climate change (Garcia-Reyes and Largier, 2010) may impact marine animals. Local extremes in several factors, associated with upwelling (e.g., oxygen, $\mathrm{pH}$, and temperature), could be stressful for the population. In particular, juveniles and other sensitive life stages may be highly vulnerable to these extremes. To date, 
however, few experimental studies have evaluated the influence of upwelling-related exposure to low-pH and low- $\mathrm{O}_{2}$ events on the mortality or growth of nearshore marine animals.

Individual variation in response to elevated environmental $\mathrm{CO}_{2}$ and decreased $\mathrm{O}_{2}$ is another concern when investigating the response of organisms to upwelling events. Even when environmental change causes significant negative impacts on most individuals' performance, tolerance by a subset of the population may promote adaptation for population persistence (Sih et al., 2012; Charmantier et al., 2008). High variation among individuals in response to elevated $\mathrm{CO}_{2}$ has been shown to represent genetic diversity in populations of some marine taxa (Sunday et al., 2011; Langer et al., 2006; Pistevos et al., 2011), and this high individual variation could benefit the population and species as a whole.

Here we examine the effect of fluctuating exposure to low-pH and low-oxygen water on juvenile stages of the red abalone, Haliotis rufescens. The red abalone is a large gastropod mollusk inhabiting lower intertidal to shallow subtidal (to $30 \mathrm{~m}$ depth) environments from Oregon to Baja California (Micheli et al., 2008; Rogers-Bennett et al., 2007). As a key recreational fishery and aquaculture resource in California, it is legally harvested north of San Francisco and also cultured in abalone farms. To assess the sustainability of red abalone populations, their sensitivity to current environmental stressors should be identified. We investigated how fluctuating exposure to low-pH and low-oxygen waters affects the mortality and growth of juvenile abalone using a pulse exposure experiment mimicking upwelling conditions. Booth et al. (2012) reported that the mean duration of upwelling nearshore water (17 $\mathrm{m}$ in depth) with $\mathrm{pH} 7.6$ and DO $4.6 \mathrm{mg} \mathrm{L}^{-1}$ off Monterey CA is $2.4 \mathrm{~h}$, with a maximum duration of $40 \mathrm{~h}$. Moreover, $\mathrm{pH}$ can drop dramatically by ca. 0.4 units within an hour. First, we studied the effects of short-term (3-6h) exposure to low-pH (pH 7.5) and low-oxygen $\left(5 \mathrm{mg} \mathrm{L}^{-1}\right)$ conditions that occur typically during coastal upwelling events (Booth et al., 2012). Second, to determine how abalones respond to prolonged low-pH and hypoxic events, we extended the exposure to "upwelling" conditions to $24 \mathrm{~h}$ twice within a 2 -week period - an uncommon but occasional event in upwelling regions (Booth et al., 2012; Micheli et al., 2012).

\section{Materials and methods}

\subsection{Study species}

Juvenile abalones (Haliotis rufescens, shell length 4-12 mm, 4-5 months of age) were acquired from the Abalone Farm Co. located in Cayucos, California, where many individuals collected over several years from Southern California abalone populations are reared at ambient temperature (mean \pm SD: $11.9 \pm 0.76$ ). Juveniles in this study were main- tained at Hopkins Marine Station of Stanford University (HMS) in aquaria with replenishing water flow at ambient temperature (mean $\pm \mathrm{SD}: 12.6 \pm 3.4,11-13.8^{\circ} \mathrm{C}$ ) and $\mathrm{pH}$ (mean $\pm \mathrm{SD}: 7.79 \pm 0.16$, ranges: 7.61-7.98). They were fed ad libitum $^{\circledR}$ algae wafers every other day. The opening of each jar was covered by a $12 \mathrm{~cm} \times 12 \mathrm{~cm}$ nylon mesh $(1 \mathrm{~mm} \times 1 \mathrm{~mm}$ mesh size), secured with a rubber band. For each experiment, jars with juvenile abalone were maintained at HMS for 3 days. Jars were then transferred to the Monterey Bay Aquarium Research Institute (MBARI), Moss Landing, California, and immersed in a transparent plastic holding tank $(60 \times 30 \times 35 \mathrm{~cm})$ with flow-through circulation in a chilled environmental chamber for at least 3 days for acclimation. The water temperature of the holding tank was maintained at approx. $9^{\circ} \mathrm{C}$ using two heaters, and water $\mathrm{pH}_{\mathrm{T}}$ (total scale) was maintained at $\mathrm{pH} 8.0$ (normal).

\subsection{Treatment protocol}

Three treatments with two different levels of $\mathrm{pH}$ and oxygen were used: (1) low $\mathrm{pH}(7.5)$ with low $\mathrm{O}_{2}$ (40\% saturation, $\left.5 \mathrm{mg} \mathrm{L}^{-1}\right)$; (2) high $\mathrm{pH}(8.0)$ with low $\mathrm{O}_{2}$; and (3) high $\mathrm{pH}(8.0)$ with high $\mathrm{O}_{2}\left(100 \%\right.$ saturation, $\left.12 \mathrm{mg} \mathrm{L}^{-1}\right)$ as a control (Table 1). A low-pH and high-DO treatment was not included in this experiment due to space, and because the primary focus of the experiment concerned the effects of upwelling conditions rather than acidification alone.

Seawater $\mathrm{pH}$, oxygen, and temperature levels were controlled using a gas-regulated aquarium system (Barry et al., 2008). This system is capable of modifying ambient seawater from MBARI's ocean intake to produce water with specified $\mathrm{pH}, p \mathrm{O}_{2}$, and temperature. For each treatment, water produced by the control system was delivered at approx. $30 \mathrm{~mL} \mathrm{~min}^{-1}$ to each jar through a $3 \mathrm{~cm}$ diameter PVC manifold, and a $10 \mathrm{~mm}$ diameter hose. Consequently, when experimental animals in the holding tanks were transitioned to treatment conditions ( $\left.\Delta \mathrm{pH}, \Delta p \mathrm{O}_{2}\right)$, inflowing treatment waters would mix with normal water in each jar causing the $\mathrm{pH}$ and $p \mathrm{O}_{2}$ to approach specified treatment levels over ca. 15$20 \mathrm{~min}$ as treatment waters were flushed from the jar.

Seawater temperature for all treatments was maintained at $6{ }^{\circ} \mathrm{C}$. Though this low temperature may be near the minimum level tolerable level for red abalone, the two to three degree difference between the holding tank and treatment water effectively mimicked the temperature reduction associated with upwelling in the central and northern Pacific coast of USA (e.g., Point St. George, CA, and Oregon).

The $\mathrm{pH}$ and $\mathrm{DO}$ of seawater of treatment waters produced by the aquarium control system were monitored continuously. In addition, conditions were measured in one randomly selected jar at least twice for each exposure period, using a portable $\mathrm{pH}$, DO meter (Thermo Scientific ${ }^{\circledR}$ : Orion 5 Star Series) (Table 1). Continuous monitoring of $\mathrm{pH}$ in control waters in the aquarium system was not available for the experimental period. Measurements of the ambient $\mathrm{pH}$ water 
Table 1. Carbonate system and other physical parameters for experimental treatments measuring the response of juvenile abalone to upwelling conditions (mean $\pm \mathrm{SD}$ ).

\begin{tabular}{|c|c|c|c|}
\hline \multirow[t]{2}{*}{ Variable } & \multicolumn{3}{|c|}{ Treatments } \\
\hline & $\begin{array}{r}\text { High pH \& low } \mathrm{O}_{2} \\
\text { (low-oxygen) }\end{array}$ & $\begin{array}{r}\text { Low pH \& low } \mathrm{O}_{2} \\
\text { (upwelling) }\end{array}$ & $\begin{array}{r}\text { High pH \& high } \mathrm{O}_{2} \\
(\text { control })\end{array}$ \\
\hline Measured pH (total scale) & $8.00 \pm 0.05$ & $7.51 \pm 0.08$ & $7.93 \pm 0.03$ \\
\hline $\mathrm{DO}\left(\mathrm{mg} \mathrm{L}^{-1}\right)$ & $5.99 \pm 0.91$ & $6.38 \pm 1.53$ & $11.68 \pm 2.86$ \\
\hline Salinity (ppt) & $33.0 \pm 0.1$ & $33.0 \pm 0.1$ & $33.0 \pm 0.1$ \\
\hline Temperature $\left({ }^{\circ} \mathrm{C}\right)$ & $6.0 \pm 0.0$ & $6.0 \pm 0.0$ & $6.0 \pm 0.0$ \\
\hline $\mathrm{PCO}_{2}(\mu \mathrm{atm})$ & $434.36 \pm 47.33$ & $1424.36 \pm 224.91$ & $535.48 \pm 23.65$ \\
\hline Alkalinity $\left(\mu \mathrm{Eq} \mathrm{kg}{ }^{-1}\right)$ & $2249.75 \pm 80.59$ & $2217.70 \pm 73.34$ & $2310.09 \pm 152.68$ \\
\hline Calcite saturation & $2.43 \pm 0.38$ & $0.85 \pm 0.19$ & $2.23 \pm 0.25$ \\
\hline Aragonite saturation & $1.53 \pm 0.23$ & $0.54 \pm 0.12$ & $1.41 \pm 0.16$ \\
\hline $\mathrm{HCO}_{3}^{-}\left(\mu\right.$ mole kg $\left.{ }^{-1}\right)$ & $1993.14 \pm 43.57$ & $2125.44 \pm 56.19$ & $2076.88 \pm 130.79$ \\
\hline $\mathrm{CO}_{3}^{2--}\left(\mu\right.$ mole $\left.\mathrm{kg}^{-1}\right)$ & $100.86 \pm 15.67$ & $35.40 \pm 7.80$ & $92.58 \pm 10.55$ \\
\hline
\end{tabular}

The parameters were calculated with $\mathrm{CO} 2$ sys (Pierrot et al., 2006) using the $\mathrm{pH}$ and $\mathrm{TCO}_{2}$ values with dissociation constants from Dickson and Millero (1987) and $\mathrm{KSO}_{4}$ using Dickson (1990).

(nominal pH 8.0) at MBARI performed before (26 October, 22 November, 16 December 2010) and after the experiment (30 March 2011) using the spectrophotometric method of Dickson et al. (2007) were pH 7.99 \pm 0.04 (SD), and were very similar to values measured for the high-pH with low- $\mathrm{O}_{2}$ $(\mathrm{pH} 8.01 \pm 0.18)$ treatment and control (high-pH with high$\left.\mathrm{O}_{2}\right)$ treatment $(\mathrm{pH} 8.09 \pm 0.18)$ during the experiment using a portable $\mathrm{pH}$ meter. Therefore, we assumed that there was little deviation from $\mathrm{pH} 8.0$ both in the high-pH treatment water and in normal water in the holding tank at MBARI. However, aquaria at HMS during the recovery period for Experiment II experienced rather low pH (see Fig. 1a). pH meters were regularly calibrated with $\mathrm{pH}$ values of Fisher Scientific ${ }^{\circledR}$ buffer salt solutions ( $\mathrm{pH} 6.86$ and $\mathrm{pH} 9.18$, total scale) measured by a UV spectrophotometer (UV-1601 Shimadzu $\left.{ }^{\circledR}\right)$. To determine the calcite and aragonite saturation states of treatment waters, samples were collected from the low $\mathrm{pH} /$ low $\mathrm{O}_{2}$ and the high- $\mathrm{pH} / \mathrm{low}-\mathrm{O}_{2}$ treatments three times after the experiment. $\mathrm{pH}$ of the samples was measured using the spectrophotometric method (Dickson et al., 2007), and DIC (dissolved inorganic carbon) was measured by nondispersive infrared analysis (LI-COR model 6262), as detailed by Friederich et al. (2002)

\subsection{Experiment I}

We tested the effects of repeated short-term exposure on the mortality of juvenile abalone in a controlled laboratory experiment. Twenty juvenile abalone individuals (mean $\pm \mathrm{SD}$ shell length: $7.36 \pm 0.76 \mathrm{~mm}$ ) were assigned to each of twelve $500 \mathrm{~mL}$ transparent glass jars with seawater. After 3 days of acclimation to natural (high $\mathrm{O}_{2} \quad(100 \%$ sat.), high- $\mathrm{pH}_{\mathrm{T}}(8.0)$ ) conditions in the holding tank, 4 randomly selected jars were assigned to each of 3 treatments (high $\mathrm{pH}$ with high $\mathrm{O}_{2}=$ "control"; low pH with low
$\mathrm{O}_{2}=$ "upwelling"; high pH with low $\mathrm{O}_{2}=$ "low oxygen"). At the completion of the acclimation period, abalones were exposed to their assigned treatment for $3 \mathrm{~h}$, then returned to the holding tank for 3 days. For this $3 \mathrm{~h}$ treatment, the 3-D control cycle was then repeated once. Abalones were then exposed to treatment conditions for $6 \mathrm{~h}$, followed by a 2 -week recovery period (see Fig. 1).

The mortality of juvenile abalone in each jar was checked immediately after exposure to treatment conditions and daily during the 3-day and 2-week recovery periods. To determine the live/dead status of juvenile abalone, they were overturned and then pricked using a dissecting pin. Individuals that did not respond to the pin were considered dead, and were transferred to vials containing $70 \%$ ethanol solution. Due to the short duration of this experiment, growth rates of abalone were not measured.

\subsection{Experiment II}

To test the effects of more prolonged periods of exposure to upwelling waters, we used an experimental protocol similar to Experiment I, but with extended periods of exposure to treatment waters. Twelve abalone juveniles (mean $\pm \mathrm{SD}$, shell length: $7.42 \pm 1.23 \mathrm{~mm}$ ) were allotted to each of 18 jars. Each individual was marked with a combination of color dots on the shell using paint markers, which were then coated with instant glue to preserve the color coding. The shell length and width of each individual was measured using a digital caliper to the nearest $0.01 \mathrm{~mm}$. The control and treatment waters were the same as those used in the previous experiment. After an acclimation period of 3 days under control conditions, abalones were exposed to their assigned treatment conditions for $24 \mathrm{~h}$, followed by immersion in water in the holding tank for 6 days. Abalones were then returned for $24 \mathrm{~h}$ to treatment waters, and then immersed in the holding tank for 


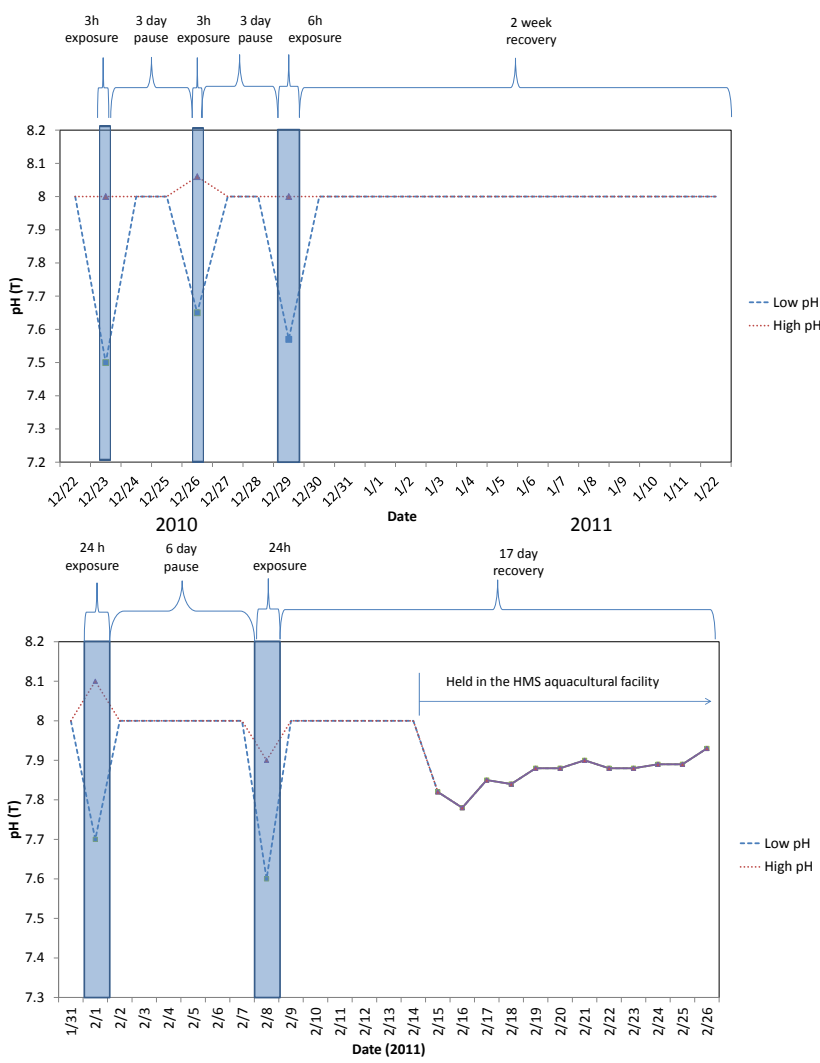

Fig. 1. Diagram describing treatment exposure and recovery schedule and $\mathrm{pH}$ values changing for (a) Experiment I and (b) Experiment II. Red triangle (high $\mathrm{pH}$ ) and blue square (low $\mathrm{pH}$ ) dots represent the $\mathrm{pH}$ values measured using a $\mathrm{pH}$ meter, and dashed line represents the assumed $\mathrm{pH}$ value throughout the experiment.

6 days again and then returned to the aquarium at HMS for recovery and immersed for 11 days (Fig. 1). The survival of each abalone was checked on the 1st, 2nd, 3rd, 5th, and 6th day after each exposure. The shell length and width of each individual were measured after its death or at the end of the experiment, for both exposures.

\subsection{Statistical analyses}

Mortality was calculated by dividing the number of dead abalone by the number of abalone initially placed in each jar. We calculated the cumulative mortality of all abalone in each jar after each exposure time point and used repeatedmeasures, one-way ANOVA for each exposure, including post-exposure periods because we expected each exposure to have a separate impact on their mortality. Repeated-measures ANOVA was then applied to the entire experimental period with the same abalone group. We confirmed that mortality on the day just before the next exposure was not significantly different, so there is no more latent impact of first exposure. In all repeated-measures analyses, the assumption of equal between-group correlations and group vari- ances ("sphericity") was not violated (Mauchly's test, all $p>0.05$ ). When significant differences were detected among treatments, Tukey tests were applied for post hoc comparisons.

The daily proportional rate of change in shell length (growth) was calculated as

$\frac{L_{\mathrm{f}}-L_{\mathrm{i}}}{L_{\mathrm{i}}} \times \frac{1}{D_{\mathrm{if}}}$,

where $L_{\mathrm{f}}$ is the final shell length at the time of death or at the end of the experiment, $L_{\mathrm{i}}$ the initial shell length measured before the exposure experiment, and $D_{\text {if }}$ the interval (days) between measurements of initial shell length and final shell length.

We assumed linear growth for juvenile abalone because their shell lengths were similar at the beginning of the experiments (for both experiments), and the experimental period was short. To evaluate the relationship between size and growth, we plotted daily proportional growth rate versus initial shell size and found no significant slope $\left(F_{1,149}=1.80\right.$, $p=0.1818$ ), indicating that, at least in the range of sizes used here, growth rate is unrelated to initial size.

To verify if both treatment level and live/dead status at the end of the experiment influence the proportional shell growth, we applied a two-way ANOVA. All growth data were transformed by arcsine square root prior to analysis. Fisher's protected least significant difference (PLSD) tests were applied for post hoc comparisons. An $F$ test of equality for variances was used to determine differences in the variance of growth rate between treatments.

\section{Results}

\subsection{Experiment I}

Abalone mortality did not differ among treatments during both $3 \mathrm{~h}$ exposure periods (1st exposure: $F_{2,9}=1.286$, $p=0.322$; 2nd exposure: no mortality in any treatments) or during the 3 days after those exposures (1st exposure: $F_{2,9}=0.300, p=0.7479$, 2nd exposure: $F_{2,9}=1.544$, $p=0.265$, Fig. 2a). There was also no significant difference in mortality between treatments during the $6 \mathrm{~h}$ exposure $\left(F_{2,9}=1.000, p=0.405\right)$ or post-exposure periods $\left(F_{2,9}=0.459, p=0.645\right.$, Fig. 1a). Overall, there was no significant difference in cumulative mortality among treatments during Experiment I $\left(F_{2,9}=0.175, p=0.841\right)$.

\subsection{Experiment II}

Repeated-measures ANOVA indicated significant variation in mortality among treatments following $24 \mathrm{~h}$ exposures to treatment levels, for up to 3 days after exposure ( 2 days: $F_{2,15}=4.059, p=0.039,3$ days: $F_{2,15}=3.966, p=0.041$, Fig. 2b). Mortality was significantly higher in the lowoxygen treatment than in the control (Tukey post hoc test, 
(a)

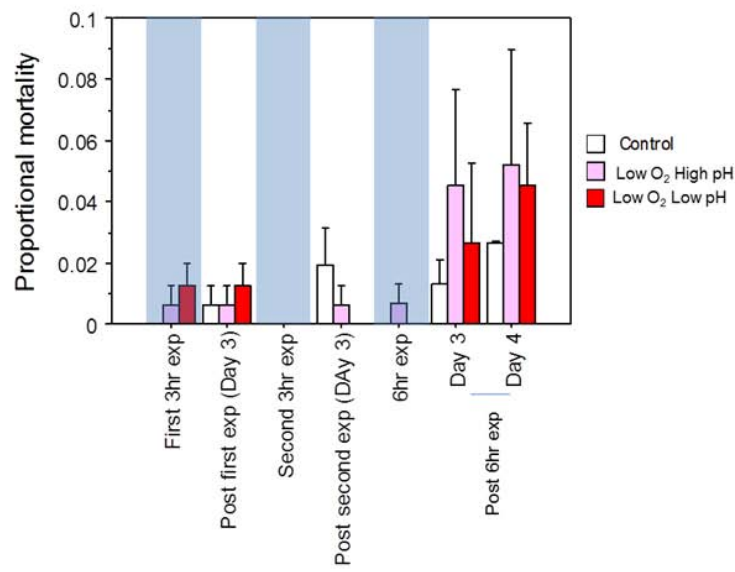

(b)

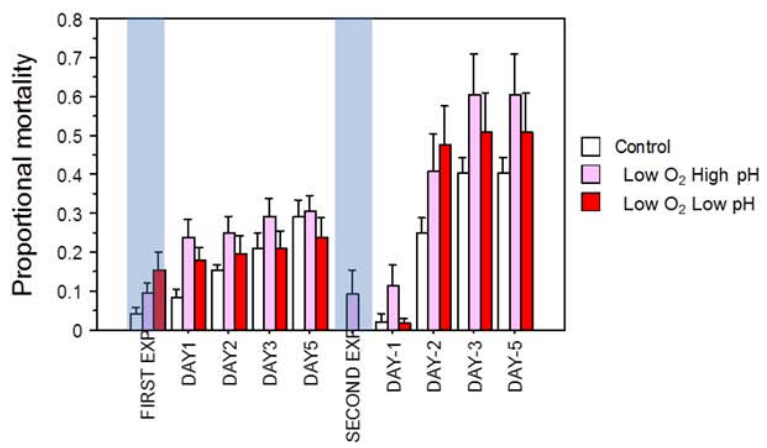

Fig. 2. Haliotis rufescens: cumulative mortality (mean \pm s.e.) of juveniles abalone after each exposure to control, upwelling, and lowoxygen treatments. (a) Experiment I. (b) Experiment II. Shaded days represent exposure of abalones to different treatments. The day number represents the days after the exposure treatment.

$p=0.035$ ), but all other comparisons among treatments were not significant. Cumulative mortality over 4 days after exposure to control or treatment conditions did not vary significantly, indicating that the effects of exposure may not persist beyond 4 days.

After the first $24 \mathrm{~h}$ exposure, the daily proportional growth rate did not differ among treatments (ANOVA: $\left.F_{2,27}=3.168, p=0.0586\right)$. By the end of the second $24 \mathrm{~h}$ exposure to treatment conditions, growth rates differed significantly between treatments $\left(F_{2,149}=16.509, p<0.0001\right.$, Fig. 3). In fact, shells in the upwelling treatment (low $\mathrm{pH}$ and low $\mathrm{O}_{2}$ ) showed negative growth, significantly lower than for animals from control or low-oxygen conditions $(p<0.0001$ for both). Variation in growth rate was significantly different between treatments ( $F$ test of variance: $F_{2,149}=16.509$, $p<0.0001)$. In particular, it was higher in the upwelling treatment than in control ( $F$ test of variance: $F_{53,50}=0.411$, $p<0.0001)$ and low-oxygen treatments $\left(F_{49,52}=0.411\right)$.

Whether abalone individuals died during the experiment was not related to differences in growth. Compari-

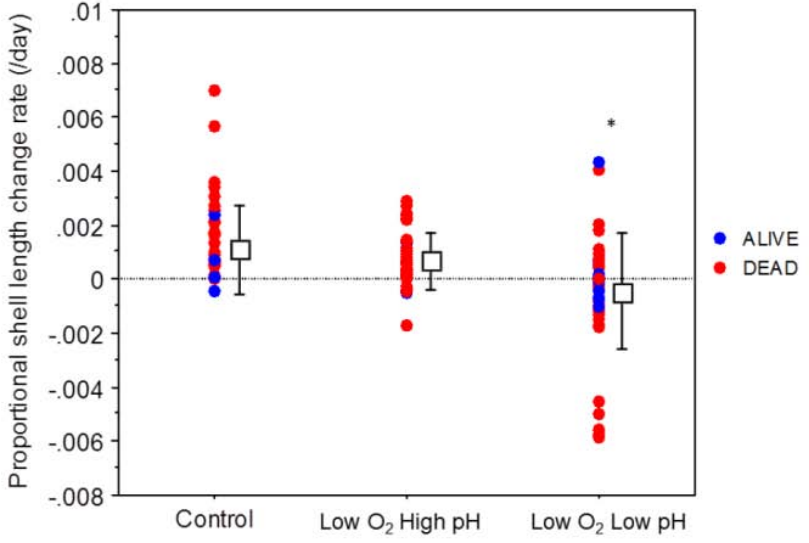

Fig. 3. Haliotis rufescens: daily proportional change in shell length (mean \pm s.e.) of juveniles among control, upwelling, or low-oxygen treatments.

son of "alive" or "dead" status or its interaction with treatment did not influence the growth rate (two-way ANOVA: alive/dead status: $F_{1,146}=0.116, p=0.7343$, alive/dead status $\times$ treatment: $F_{1,146}=1.011, p=0.3665$ ).

\section{Discussion}

These experiments indicate that repeated short-term $(3-6 \mathrm{~h})$ exposure of abalone juveniles to conditions documented during upwelling (Booth, 2011) has no detectable immediate effect on their survival. In contrast, periodic, prolonged exposure $(24 \mathrm{~h}$ twice) to low oxygen significantly decreased survival, and exposure to upwelling treatment significantly reduced the shell growth. These results suggest that abalone populations may be adapted to fluctuations in $\mathrm{pH}$ and $\mathrm{O}_{2}$ over timescales typically occurring along the central California coast, but not to a more prolonged duration of low $\mathrm{pH}$ and $\mathrm{O}_{2}$ similar to those documented off the coast of Mexico (Micheli et al., 2012). Low $\mathrm{O}_{2}$ may always be stressful, but tolerable for short periods. Extended periods of hypoxia and/or hypercapnia may lead to accumulation of impacts and eventually reduced growth or death.

Because extended exposure to low oxygen per se has lethal effects on juvenile abalone, oxygen concentration is likely to be a crucial factor influencing the persistence of abalone populations. However, seawater $\mathrm{pH}$ should be also considered as an important factor influencing abalone populations because low $\mathrm{pH}$ has a deleterious effect on growth. Growth can influence reproductive success and susceptibility to predation (Rossetto et al., 2012). Shell length of individuals exposed to the low-pH, low- $\mathrm{O}_{2}$ treatment simulating upwelled waters decreased, suggesting that shells were dissolving in the low$\mathrm{pH}$ water. Given that ocean acidification did not change the expression of shell growth genes in the larval stage in a previous experiment (Zippay and Hofmann, 2010), epigenetic 
processes or differential physiological investment might have influenced the shell growth. The aragonite and calcite saturation states of the upwelling treatment waters were less than 1 (Table 1), which should increase the energetic cost of shell formation for abalone (Portner, 2008; Byrne et al., 2011).

The effects of low $\mathrm{pH}$ and low oxygen may have different effects on the growth of different life stages and different species. Interestingly, mortality did not differ between the control and upwelling treatment with low $\mathrm{pH}$ and low $\mathrm{O}_{2}$. Our expectation was that exposure to low-pH waters during upwelling, coupled with low oxygen levels, would be the most stressful, leading to reduced survival or growth or both. Our results suggest otherwise, and further information is required to understand the combined effects of $\mathrm{pH}$ and $\mathrm{O}_{2}$ on abalone performance.

We cannot explain the difference in mortality rates between two experiments even in the control treatment and speculate that extended exposure to low temperature associated with upwelling conditions may also lead to higher mortality. Alternatively, there may be differences in the general health of abalone among batches of juveniles obtained from the Abalone Farm that contributed to differences in mortality between experiments. Obviously, other unknown processes may be involved.

Although very few data are available concerning variation in the carbonate chemistry of nearshore waters in Monterey Bay, time-series measurements of conditions at the intake pipe for the Monterey Bay Aquarium indicate that the average duration of upwelling conditions $\left(\sim 4.6 \mathrm{mg} \mathrm{L}^{-1}\right.$ $\mathrm{O}_{2}, \mathrm{pH} \sim 7.6$ ) in nearshore Monterey Bay environments is $2.4 \pm 2.6 \mathrm{~h}$ (Booth, 2011). Juvenile abalone appear to have the capacity to cope with short exposure to these conditions. Prolonged upwelling conditions stressful to juvenile abalone may occur only rarely. Over the past $12 \mathrm{yr}$, the maximum observed duration of low-oxygen and low-pH events nearshore Monterey Bay was $40 \mathrm{~h}$ (Booth, 2011), similar to recent measurements off Baja California (Micheli et al., 2012). A trend towards prolonged upwelling conditions associated with recent climatic changes (Garcia-Reyes and Largier, 2010) is expected to increase the frequency and duration of lowoxygen, low-pH events (Feely et al., 2008; Nam et al., 2011; Melzner et al., 2013), possibly leading to more frequent prolonged exposure.

Prolonged upwelling conditions can have a significant impact on the growth of juvenile abalone, and possibly other calcifying, marine invertebrates (e.g., Vaquer-Sunyer and Duarte, 2008; Kroeker et al., 2010). Changes in individual performance (growth, survival, reproduction) of abalone in response to future ocean conditions will likely have significant but poorly known effects on the demographic dynamics of California abalone populations and the ecology of nearshore ecosystems.

Our observation of increased individual variation in growth rate after exposure to upwelling conditions is intriguing. Such variation among individuals suggests that pheno- typic plasticity or genetic variation or both promote a range of performance within the population in response to shifts in $\mathrm{pH}$ and oxygen. While a large portion of the population may experience reduced growth or survival, some individuals may acclimate to extended upwelling events by maintaining their calcification, thereby promoting adaptation through enhanced survival and fitness by this subpopulation. This is in agreement with results of other studies that have shown high individual variation of marine animals in response to low-pH conditions (Sunday et al., 2011; Schlegel et al., 2012; Pistevos et al., 2011). Phenotypic plasticity of abalone populations may explain higher individual variation in growth rate in response to low $\mathrm{pH}$ and low oxygen. Cryptic genetic variation might also be expressed when juveniles are exposed to the novel environments (Ghalambor et al., 2007). Some part of the reaction norm can be adaptive to new conditions. If such adaptive variation is heritable, red abalone may be able to adapt to extended exposure to upwelling conditions. Indeed, recent genetic information on red abalone suggests that genes for biomineralization and resistance to hypoxia are under selection in upwelling regions (de Wit and Palumbi, 2013). Gene expression studies of abalone responses to upwelling conditions are likely to shed light on this issue.

Low- $\mathrm{O}_{2}$ and low-pH events during upwelling periods are largely coupled because these parameters are regulated by respiratory oxygen consumption and carbon dioxide release by the deep water biological community. Advection of deeper, low- $\mathrm{O}_{2}$, low-pH waters toward the surface and inshore leads to exposure of coastal taxa to potentially stressful environmental conditions (Bianucci et al., 2011; Nam et al., 2011). Future increases in the influx of $\mathrm{CO}_{2}$ from the atmosphere to the ocean will further reduce the $\mathrm{pH}$ of upwelled waters (Feely et al., 2008, 2010), and will decouple, to some extent, the linkage between oxygen and carbon dioxide in these waters. This study did not assess the influence of increasing temperature, which is also changing with upwelling, $\mathrm{pH}$, and oxygen. Further studies of the effects of projected changes in ocean conditions in upwelling regimes on diverse nearshore species are needed to understand and predict future shifts in the structure and function of coastal ecosystems.

Acknowledgements. We thank R. Fields and the Abalone Farm in Cayucos, California, for kindly providing juvenile red abalone for research purposes. We are also grateful to C. Lovera for helping setting up the abalone experiment at MBARI and J. Taylor for providing the data for seawater chemistry. This research was supported by the National Research Foundation of Korea Grant funded by the Korean Government (Ministry of Education, Science and Technology) to T. W. Kim (NRF-2010-357-C00129), a Chambers fellowship to F. Micheli, and by Monterey Bay Aquarium Research Institute.

Edited by: D. Schmidt 


\section{References}

Alenius, B. and Munguia, P.: Effects of $\mathrm{pH}$ variability on the intertidal isopod, Paradella dianae, Mar. Freshw. Beh. Phy., 45, 245259, doi:10.1080/10236244.2012.727235, 2012.

Barry, J. P., Lovera, C., Okuda, C., Nelson, E., and Pane, E. F.: A gas-controlled aquarium system for ocean acidification studies, IEEE Xplore, 978-1-4244-2126-8/08/, 2008.

Bianucci, L., Denman, K., and Ianson, D.: Low oxygen and high inorganic carbon on the Vancouver Island Shelf, J. Geophys. Res.Oceans, 116, C07011, doi:10.1029/2010JC006720, 2011.

Bibby, R., Cleall-Harding, P., Rundle, S., Widdicombe, S., and Spicer, J.: Ocean acidification disrupts induced defences in the intertidal gastropod Littorina littorea, Biol. Lett., 3, 699-701, 2007.

Booth, A.: Hypoxic and low $\mathrm{pH}$ water in the nearshore marine environments of Monterey Bay, California: characterizing a decade of oxygen and $\mathrm{pH}$, and drivers of variability, Master thesis, Moss Landing Marine Laboratories, 122 pp., 2011.

Booth, J., McPhee-Shaw, E., Chua, P., Kingsley, E., Denny, M., Phillips, R., Bograd, S., Zeidberg, L., and Gilly, W.: Natural intrusions of hypoxic, low $\mathrm{pH}$ water into nearshore marine environments on the California coast, Cont. Shelf Res., 45, 108-115, doi:10.1016/j.csr.2012.06.009, 2012.

Byrne, M., Ho, M., Wong, E., Soars, N. A., Selvakumaraswamy, P., Shepard-Brennand, H., Dworjanyn, S. A., and Davis, A. R.: Unshelled abalone and corrupted urchins: development of marine calcifiers in a changing ocean, P. Roy. Soc. B-Biol. Sci., 278, 2376-2383, 2011.

Charmantier, A., McCleery, R., Cole, L., Perrins, C., Kruuk, L., and Sheldon, B.: Adaptive phenotypic plasticity in response to climate change in a wild bird population, Science, 320, 800-803, doi:10.1126/science.1157174, 2008.

de Wit, P. and Palumbi, S.: Transcriptome-wide polymorphisms of red abalone (Haliotis rufescens) reveal patterns of gene flow and local adaptation, Mol. Ecol., 22, 2884-2897, doi:10.1111/mec.12081, 2013.

Dickson, A. G.: Thermodynamics of the dissociation of boric-acid in synthetic seawater form 273.15 K to 318.15 K, Deep Sea Res., 37, 755-766, doi:10.1016/0198-0149(90)90004-F, 1990.

Dickson, A. G. and Millero, F. J.: A comparison of the equilibrium constants for the dissociation of carbonic-acid in seawater media, Deep Sea Res., 34, 1733-1743, 1987.

Dickson, A. G., Sabine, C. L., and Christian, J. R.: Guide to Best Practices for Ocean $\mathrm{CO}_{2}$ Measurements, in: PICES Special Publication 3, 191 pp., 2007.

Dupont, S., Ortega-Martinez, O., and Thorndyke, M.: Impact of near-future ocean acidification on echinoderms, Ecotoxicology, 19, 449-462, 2010.

Feely, R., Sabine, C., Hernandez-Ayon, J., Ianson, D., and Hales, B.: Evidence for upwelling of corrosive "acidified" water onto the continental shelf, Science, 320, 1490-1492, doi:10.1126/science.1155676, 2008.

Feely, R., Alin, S., Newton, J., Sabine, C., Warner, M., Devol, A., Krembs, C., and Maloy, C.: The combined effects of ocean acidification, mixing, and respiration on $\mathrm{pH}$ and carbonate saturation in an urbanized estuary, Estuar. Coast. Shelf S., 88, 442-449, doi:10.1016/j.ecss.2010.05.004, 2010.

Friederich, G., Walz, P., Burczynski, M., and Chavez, F.: Inorganic carbon in the central California upwelling system during the
1997-1999 El Nino-La Nina event, Prog. Oceanogr., 54, 185203, doi:10.1016/S0079-6611(02)00049-6, 2002.

Garcia-Reyes, M. and Largier, J.: Observations of increased winddriven coastal upwelling off central California, J. Geophys. Res.Oceans, 115, C0411, doi:10.1029/2009JC005576, 2010.

Ghalambor, C., McKay, J., Carroll, S., and Reznick, D.: Adaptive versus non-adaptive phenotypic plasticity and the potential for contemporary adaptation in new environments, Funct. Ecol., 21, 394-407, doi:10.1111/j.1365-2435.2007.01283.x, 2007.

Grantham, B., Chan, F., Nielsen, K., Fox, D., Barth, J., Huyer, A., Lubchenco, J., and Menge, B.: Upwelling-driven nearshore hypoxia signals ecosystem and oceanographic changes in the northeast Pacific, Nature, 429, 749-754, doi:10.1038/nature02605, 2004.

Hauri, C., Gruber, N., Plattner, G., Alin, S., Feely, R., Hales, B., and Wheeler, P.: Ocean acidification in the California current system, Oceanography, 22, 60-71, 2009.

Hofmann, G. E., Barry, J. P., Edmunds, P. J., Gates, R. D., Hutchins, D. A., Klinger, T., and Sewell, M. A.: The effect of ocean acidification on calcifying organisms in marine ecosystems: an organism-to-ecosystem perspective, Annu. Rev. Ecol. Evol. Syst., 41, 127-147, 2010.

Kroeker, K., Kordas, R., Crim, R., and Singh, G.: Meta-analysis reveals negative yet variable effects of ocean acidification on marine organisms, Ecol. Lett., 13, 1419-1434, doi:10.1111/j.14610248.2010.01518.x, 2010.

Langer, G., Geisen, M., Baumann, K., Klas, J., Riebesell, U., Thoms, S., and Young, J.: Species-specific responses of calcifying algae to changing seawater carbonate chemistry, Geochem. Geophy. Geosy., 7, Q09006, doi:10.1029/2005GC001227, 2006.

Melzner, F., Thomsen, J., Koeve, W., Oschlies, A., Gutowska, M., Bange, H., Hansen, H., and Körtzinger, A.: Future ocean acidification will be amplified by hypoxia in coastal habitats, Mar. Biol., 160, 1875-1888, doi:10.1007/s00227-012-1954-1, 2013.

Micheli, F., Shelton, A. O., Bushinsky, S. M., Chiu, A. L., Haupt, A. J., Heiman, K. W., Kappel, C. V., Lynch, M. C., Martone, R. G., Dunbar, R. B., and Watanabe, J.: Persistence of depleted abalones in marine reserves of central California, Biol. Conserv., 141, 1078-1090, 2008.

Micheli, F., Saenz-Arroyo, A., Greenley, A., Vazquez, L., Espinoza, A., Rossetto, M., and De Leo, G.: Evidence that marine reserves enhance resilience to climatic impacts, PLOS ONE, 7, e40832, doi:10.1371/journal.pone.0040832, 2012.

Nam, S., Kim, H.-J., and Send, U.: Amplification of hypoxic and acidic events by La Niña conditions on the continental shelf off California, Geophys. Res. Lett., 38, L22602, doi:10.1029/2011g1049549, 2011.

Orr, J. C., Fabry, V. J., Aumont, O., Bopp, L., Doney, S. C., Feely, R. A., Gnanadesikan, A., Gruber, N., Ishida, A., Joos, F., Key, R. M., Lindsay, K., Maier-Reimer, E., Matear, R., Monfray, P., Mouchet, A., Najjar, R. G., Plattner, G. K., Rodgers, K. B., Sabine, C. L., Sarmiento, J. L., Schlitzer, R., Slater, R. D., Totterdell, I. J., Weirig, M. F., Yamanaka, Y., and Yool, A.: Anthropogenic ocean acidification over the twenty-first century and its impact on calcifying organisms, Nature, 437, 681-686, 2005.

Pierrot, D., Lewis, E., and Wallace, D. W. R.: CO2SYS DOS Program Developed for CO2System Calculations. ORNL/CDIAC105., Carbon Dioxide Information Analysis Center, Oak Rid- 
geNational Laboratory, US Department of Energy, Oak Ridge, California, 2006.

Pistevos, J., Calosi, P., Widdicombe, S., and Bishop, J.: Will variation among genetic individuals influence species responses to global climate change?, Oikos, 120, 675-689, doi:10.1111/j.1600-0706.2010.19470.x, 2011.

Portner, H. O.: Ecosystem effects of ocean acidification in times of ocean warming: a physiologist's view, Mar. Ecol.-Prog. Ser., 373, 203-217, 2008.

Rogers-Bennett, L., Rogers, D., and Schultz, S.: Modeling growth and mortality of red abalone (Haliotis rufescens) in Northern California, J. Shellfish Res., 26, 719-727, 2007.

Rossetto, M., De Leo, G., Bevacqua, D., and Micheli, F.: Allometric scaling of mortality rates with body mass in abalones, Oecologia, 168, 989-996, doi:10.1007/s00442-011-2163-1, 2012.

Schlegel, P., Havenhand, J. N., Gillings, M. R., and Williamson, J. E.: Individual variability in reproductive success determines winners and losers under ocean acidification: a case study with sea urchins, PLOS ONE, 7, e53118, doi:10.1371/journal.pone.0053118, 2012.
Sih, A., Cote, J., Evans, M., Fogarty, S., and Pruitt, J.: Ecological implications of behavioural syndromes, Ecol. Lett., 15, 278-289, doi:10.1111/j.1461-0248.2011.01731.x, 2012.

Sunday, J., Crim, R., Harley, C., and Hart, M.: Quantifying rates of evolutionary adaptation in response to ocean acidification, PLOS ONE, 6, e22881, doi:10.1371/journal.pone.0022881, 2011.

Vaquer-Sunyer, R. and Duarte, C.: Thresholds of hypoxia for marine biodiversity, P. Natl. Acad. Sci. USA, 105, 15452-15457, doi:10.1073/pnas.0803833105, 2008.

Zippay, M. L. and Hofmann, G. E.: Effect of ph on gene expression and thermal tolerance of early life history stages of red abalone (Haliotis rufescens), J. Shellfish Res., 29, 429-439, 2010. 